\title{
Impact of aridization on soil cover transformation of the Aral Sea and the modern Syr-Darya Delta
}

\author{
Tomina Tatyana KONSTANTINOVNA*, Azhikina Natalya ZHEKSEMBAEVNA \\ Kazakh Research Institute of Soil Science and Agrochemistry named after Uspanov, Almaty 050060, Kazakhstan
}

\begin{abstract}
The effects of human activities on the soil cover transformation in the eastern part of Kazakhstan were investigated during the period of 1956-2008. The results of the research for different soil types in Priaralye indicated that there was $643.3 \times 10^{3} \mathrm{hm}^{2}$ solonchaks, accounting for $38.5 \%$ of the total area $\left(1670.5 \times 10^{3} \mathrm{hm}^{2}\right)$ in 2008 . Vast areas are occupied with dried lakeshore soil $\left(311.1 \times 10^{3} \mathrm{hm}^{2}\right)$, sandy soils $\left(147.6 \times 10^{3} \mathrm{hm}^{2}\right)$ and grey-brown desert soils and solonetzes $\left(146.7 \times 10^{3} \mathrm{hm}^{2}\right)$. In 2001 the area of solonchak was $755 \times 10^{3} \mathrm{hm}^{2}$ and decreased to $643.3 \times 10^{3} \mathrm{hm}^{2}$ in 2008 , which due to the shrinkage of the Aral Sea, the areas of marsh and lakeshore solonchaks decreased with the increase of dried bottom of the Aral Sea. The level of soil cover transformation in the modern delta of the Syr-Darya River can be seen from the comparison of the results obtained from the different years in the study area. The area of solonchaks increased by $10 \times 10^{3} \mathrm{hm}^{2}$ and the area of alluvial-meadow salinizied soils increased by $17.9 \times 10^{3} \mathrm{hm}^{2}$ during the period of 1956-1969. It means that many non-salinizied soils were transformed into salinizied ones. Striking changes occurred in the structure of soil cover as a result of aridization. So, the researches in1969 significantly determined the areas of hydromorphic soils subjected to desertification (it was not fixed on the map before 1956). Later, these soils were transformed into takyr-like soils. The area of takyr-like soils increased almost by 3 times for 34 years (from 1956 to 1990). The long-term soil researches on soil cover transformation in Priaralye have shown that the tendencies of negative processes (salinization and deflation) are being kept and lead to further soil and eco-environment degradation in the region.
\end{abstract}

Keywords: soil transformation; aridization; Aral Sea; Syr-Darya Delta

\section{Introduction}

Kazakh Research Institute of Soil Science and Agrochemistry named after Uspanov carried out scientific field expeditions on the area of the dry bottom of the Aral Sea and the modern delta of the Syr-Darya River during the period of 1956 to 2008. There were a lot of scientific publications on the problems of the dry bottom soils for the Aral Sea and the modern delta of the Syr-Darya River (Small et al., 2001; Krivonogov et al., 2010; Micklin, 2010). For example, the project 'Soil Monitoring of the Modern Delta of the Syr-Darya and the Dry Bottom of the Aral Sea' was accomplished during the period of 2003-2005. Monitoring researches were carried out annually by establishing soil quadrats with further soil sampling on the sites of research. The project 'Assessment of Aridization Impact on Soil Transformation in Kazakhstan Priaralye and
Development of a Scientific Basis for the Increase of their Biological Productivity' was accomplished from 2006 to 2008. Field expedition researches were carried out annually on the eastern part of the Priaralye with establishment of several soil quadrats on different types of soils with further determination of soil contours. A great volume of soil scientific researches have been accomplished by chemical analytical database for different types of soils, therefore, the photos and maps are available. The aim of researches is to investigate the soil cover transformation of the Aral Sea dry bottom and Syr-Darya modern delta under aridization.

\section{Methods}

The areas of different soils were calculated according

Received 2010-07-22; accepted 2011-01-25

doi: 10.3724/SP.J.1227.2011.00150

* Corresponding author: Tomina Tatyana KONSTANTINOVNA

(Email: ab.saparov@yahoo.com) 
to soil maps compiled on the scale $1: 200,000$ based on the soil field researches during the period of 1956-2008 (1956, 1969, 1990, 2001 and 2008). The methods include field observation and description to soil profiles, soil sampling, soil mapping, and then soil properties’ analyzing in laboratory.

\section{Results and discussion}

Irrigation development, accompanied with the river flow improvement, the increase of drawing water and consumption in the upper and middle reaches of the Syr-Darya River stream, have led to extreme deficiency of water resources, which resulted in anthropogenic aridization and transformation of soil cover. Hydromorphic soils, the most valuable in agriculture, were transformed into degraded soils in the modern delta of the Syr-Darya River. Large patches of different solonchaks were formed due to the lake shrinkage (Fig. 1).

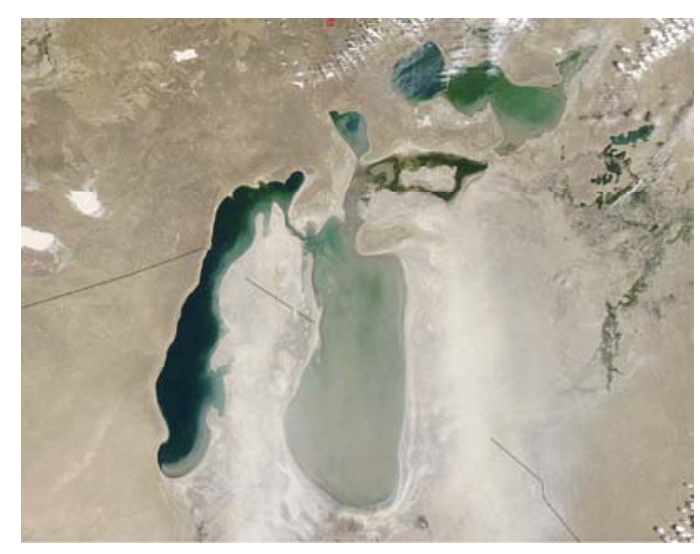

Fig. 1 Map of the Aral Sea

Flooding of the Syr-Darya River stopped after the river hydrological construction. The hydrologic regime of the delta plain changed. So, the land that was no more flooded was subjected to drying and desertification, which led to the degradation of ecosystem, the reduction of hydromorphic soil area and soil fertility, and the salinization. Against the background of arid climate, the nature of soil cover transformation on the delta land depends on the degree of hydrologic and hydrochemical factors' changes, soil-ameliorative conditions, location of the river course in the system. The greatest changes were observed in the landscapes of the Syr-Darya River modern delta (Kazazhanov and Khaibulin, 2003). As a result of climatic change, the aridity increased (Kazazhanov, 2001). With the reduction of flooding, the delta stopped to be an area of accumulation for solid and biogenic flow. The hydrophilous vegetation degraded and the differences, existed earlier in hydrological conditions on the relief elements, leveled. Reed communities disappeared on the major part of the delta after the flooding stopped. The species were replaced by meso-xerophilous vegetation of wild weeds in depressions and halo-xerophilous groups of field weeds on the margins of depressions. Herb-gramineous meadow vegetation was replaced by annual halo-meso-xerophilous ones on natural levees.

Soil salinization sharply increased on the border of the irrigated land of Kazalinsk. Initially it was caused by complex ameliorative conditions in the modern delta of the Syr-Darya River: close bedding of water retainer, and the relief with small basins; rice cultivation without engineering systems on solonchak lands leads to redistribution of salts and secondary salinization. Thus, the change of water-salt regime in the soils led to salinization development and regional redistribution of salts on the major part of the Syr-Darya River modern delta. Salt localization removed from watersheds to natural levees and lands adjacent to canals, slopes of the natural levees and boards of padings. As a whole, the process of salinization prevailed over demineralization on the dried and desertified lands. The degree of soil cover transformation can be seen from the comparison of the results obtained in the course of different year researches.

It is seen from Table 1 that the area of solonchak increased by $10 \times 10^{3} \mathrm{hm}^{2}$ from 1956 to 1969 , and the area of alluvial-meadow salinized soils increased from $22.3 \times 10^{3} \mathrm{hm}^{2}$ to $40.2 \times 10^{3} \mathrm{hm}^{2}$, i.e. many non-salinized soils were transformed into salinized ones. Striking changes took place in soil cover structure as a result of aridization. So, the areas with hydromorphic soils subjected to desertification in 1969, which was not fixed in 1956. Later these soils were transformed into takyr-like soils. The area of takyr-like soils increased almost by 3 times for 34 years (from 1956 to 1990). The process of anthropogenic aridization became slower after 1990 through the comparison of the data obtained in 1990 and 2001. The areas of takyr-like and desertified hydromorphic soils slightly increased. From the winter and early spring drafts of 
Chardara reservoir, the annual water volume of supplying the modern delta of the Syr-Darya River increased from $3.0 \times 10^{3}-3.5 \times 10^{3} \mathrm{~m}^{3}$ to $8 \times 10^{3}-9 \times 10^{3} \mathrm{~m}^{3}$ in the beginning of 2002. Either low or sometimes high sites of the delta area are subjected to flooding.

The comparison of the soil map compiled in 2001 and 2008 can make the following conclusion. Dried meadow-boggy and boggy-meadow soils were transformed into normal meadow-boggy and boggy soils in Kokkol. Meadow-boggy dried soils also were transformed into normal meadow-boggy and boggy soils in the depressions between the natural levee of the SyrDarya River and Akshatau system of lakes. A transition of some alluvial-meadow dried soils into normal ones was observed on the natural levee of the Syr-Darya River (the middle reaches). In the lower reaches of the Syr-Darya River, in which the natural levee was poorly formed, the alluvial-meadow and boggymeadow soils were transformed into meadow-boggy and boggy soils.

In part, rice field's irrigation was accompanied with the process of salinization. Sand invasion from Kyzylkum sandy land could be seen in the region of Aksai-Kuvandarya. The thickness of blown sand cover reached up to $20-30 \mathrm{~cm}$ on meadow-boggy dried soils. The process of aridization proceeds on the major part of the delta with automorphic soils (grey-brown desert soil, takyr-like soil, sandy soil and solonetz), dried and desertified hydromorphic soils. The Aral Sea shrinkage influenced the transformation of soil types in the dried zone. The formation of soil cover on the dried bottom of the Aral Sea has three basic ways:

(1) Soil development starts from marsh solonchak and proceeds through lakeshore solonchak to lakeshore soil with blown sandy cover on the light sandy and loamy luvisol from bottom outcrop.

(2) Soil formation starts from marsh solonchak through lakeshore crust-puffed, takyr-like solonchaks to takyr-like solonetz-solonchak desertified soil under heavy luviation of lake-water precipitation under the conditions of open lakeshore.

(3) The existence of enclosed basins without outflow and with highly stagnant mineralized under ground water on the dried lake bottom provides the conditions for the formation of solonchaks.

In the east lakeshore of the Aral Sea, the lake bottom consists of loamy sand soil and loam, bedded by clay and loam containing $0.4 \%$ to $1.5 \%$ of soluble salts of chloride-sulfate and sulfate-chloride. Lakeshore solonchak deprived of vegetation borders with the lake by a belt of $2-4 \mathrm{~km}$. The surface, outcropping after 1-2 years' lake flooding, is the main source of deflation and aerosol salt-dust removal and salinization of the adjacent area (Abuduwaili, 2010). The length of the salt removal made up $200-300 \mathrm{~km}$ in the west direction, and the annual volume of salt removal was $65 \times 10^{6} \mathrm{t}$. Recent research showed that about $85 \times 10^{3} \mathrm{t} / \mathrm{km}^{2}$ of salt dust was removed from dried bottom annually (Ginzburg et al., 2010). Further a wide dry belt (dried 5-6 years ago) was formed. Annual salsola was overgrown and small barkhans were developed here and there. The vegetation reduced wind-blown salt-dust removal. Zonal desert landscape with takyr-like soil and solonchak were formed on the outcropping area 10-15 years ago.

The main difference of natural complex development in two successive ways is as followings: in the first case, a sheet of land dried up, and then the process of deflation and eolian accumulation started, which is a leading factor in the course of different landscape formation including soil. In the course of the shrinkage, marsh and lakeshore solonchaks were transformed into crust puffed solonchaks or lakeshore's semi hydromorphic saline soils in 2-3 years. Later on, sandy soils or soils with takyr-like properties were formed from the soils mentioned above.

Due to the drying up of the lake, the area of solonchaks increased up to $755.3 \times 10^{3} \mathrm{hm}^{2}$ (Table 1) in 2001 (It was $94.5 \times 10^{3} \mathrm{hm}^{2}$ in 1956), i.e. the process of soil transformation proceeded in the temporal aspect under aridization. The shares of marsh and lacustrine solonchaks decreased in the total area of the dried bottom of the Aral Sea with the increase of the dry areas. The calculation of the areas for different soil types in Priaralye (in 2008) has shown that solonchaks $\left(643.3 \times 10^{3} \mathrm{hm}^{2}\right)$ were dominated in the total area of the land $\left(1670.5 \times 10^{3} \mathrm{hm}^{2}\right)$.

The long-term researches on soil cover transformation in Priaralye have shown that the soils were systematically subjected to desertification under aridization. It is demonstrated by the data of Table 1 .

The result of soil desertification process in Priaralye is the transformation of alluvial-meadow salinizied soils into alluvial-meadow desertified soils, i.e. alluvial- 

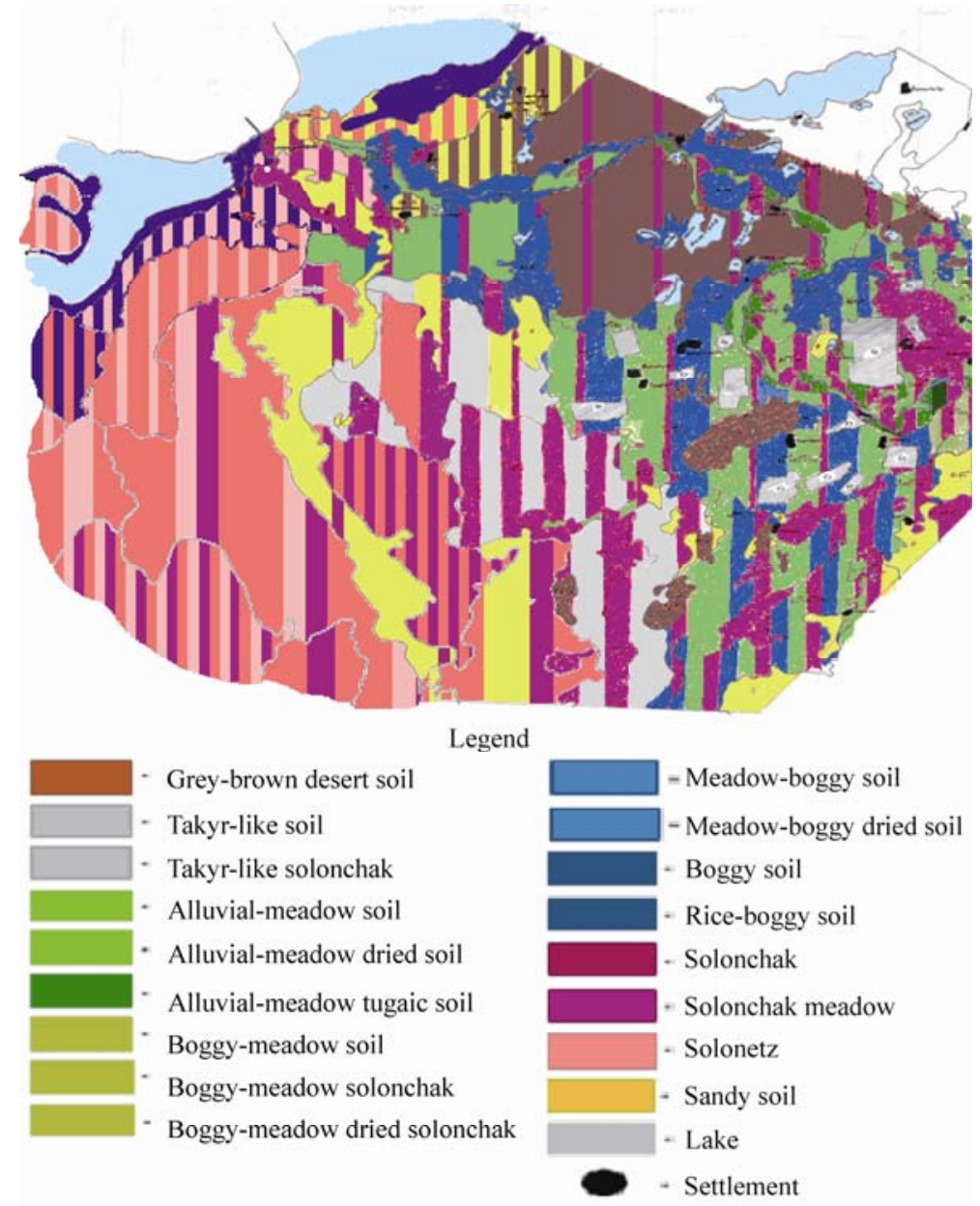

Fig. 2 The soil distribution of the modern delta of Syr-Darya River and dried bottom of the Aral Sea (2008)

Table 1 Transformation of soil covers in the modern delta of Syr-Darya River and dried bottom of the Aral Sea during the period of 1956-2008

\begin{tabular}{|c|c|c|c|c|c|c|c|c|c|c|}
\hline \multirow[b]{2}{*}{ Soils types } & \multicolumn{10}{|c|}{ Areas of soils $\left(\times 10^{3} \mathrm{hm}^{2}\right)$} \\
\hline & 1956 & $\begin{array}{l}\text { Percent } \\
\text { (\%) }\end{array}$ & 1969 & $\begin{array}{c}\text { Percent } \\
(\%)\end{array}$ & 1990 & $\begin{array}{l}\text { Percent } \\
(\%)\end{array}$ & 2001 & $\begin{array}{l}\text { Percent } \\
\text { (\%) }\end{array}$ & 2008 & $\begin{array}{c}\text { Percent } \\
\text { (\%) }\end{array}$ \\
\hline Grey-brown desert soil and solonetz & 117.1 & 18.3 & 117.4 & 18.3 & 117.5 & 9.3 & 115.1 & 7.5 & 146.7 & 8.8 \\
\hline Takyr-like soil & 24.3 & 3.8 & 31.4 & 4.9 & 67.6 & 5.3 & 68.9 & 4.5 & 80.3 & 4.8 \\
\hline $\begin{array}{l}\text { Alluvial-meadow and alluvial-meadow tugaic } \\
\text { soil }\end{array}$ & 66.4 & 10.3 & 13.3 & 2.1 & 5.9 & 0.5 & 5.5 & 0.4 & 9.6 & 0.6 \\
\hline Alluvial-meadow salinizied soil & 22.3 & 3.5 & 40.2 & 6.3 & 8.0 & 0.6 & 7.7 & 0.5 & - & - \\
\hline Alluvial-meadow desertified soil & - & - & 12.0 & 1.9 & 0.8 & 0.1 & 0.9 & 0.1 & 2.9 & 0.2 \\
\hline Boggy-meadow soil & - & - & 25.4 & 3.9 & 1.8 & 0.1 & 0.8 & 0.1 & 10.8 & 0.6 \\
\hline Boggy-meadow dried solonchak & - & - & 50.4 & 7.8 & 61.6 & 4.8 & 61.8 & 4.0 & 108.4 & 6.5 \\
\hline Boggy-meadow desertified soil & - & - & 0.5 & 0.1 & 11.7 & 0.9 & 11.8 & 0.8 & 19.0 & 1.1 \\
\hline Boggy and meadow-boggy soil & 228.1 & 35.6 & 156.4 & 24.4 & 33.0 & 2.6 & 30.8 & 2.0 & 43.4 & 2.6 \\
\hline Rice-boggy soil & - & - & - & - & 30.0 & 2.4 & 28.7 & 1.9 & 29.6 & 1.8 \\
\hline Boggy and meadow-boggy dried solonchak & - & - & 2.9 & 0.5 & 111.7 & 8.8 & 114.4 & 7.5 & 96.8 & 5.8 \\
\hline Meadow-boggy desertified soil & - & - & - & - & 6.6 & 0.5 & 8.2 & 0.5 & 9.4 & 0.6 \\
\hline Dried lakeshore soil & _- & - & - & - & 109.9 & 8.7 & 164.3 & 10.7 & 311.1 & 18.6 \\
\hline Sandy soil & 68.3 & 10.7 & 68.6 & 10.7 & 144.9 & 11.4 & 145.5 & 9.5 & 147.6 & 8.8 \\
\hline Solonchak & 94.5 & 14.7 & 104.5 & 16.3 & 430.0 & 33.9 & 755.3 & 49.3 & 643.3 & 38.5 \\
\hline Lacustrine soil & 19.3 & 3.1 & 18.0 & 2.8 & 127.8 & 10.1 & 12.3 & 0.8 & 11.6 & 0.7 \\
\hline Total & 640.3 & 100 & 641.0 & 100 & 1268.8 & 100 & 1532 & 100 & 1670.5 & 100 \\
\hline
\end{tabular}


meadow salinizied soils did not exist in 2008. And the areas of alluvial-meadow and alluvial-meadow tugaic soils have substantially decreased at present. The areas of solonchaks increased from $94.5 \times 10^{3} \mathrm{hm}^{2}$ to $643.3 \times 10^{3} \mathrm{hm}^{2}$ during the period of $1956-2008$. A similar tendency was observed in the areas of sandy soils.

\section{Conclusion}

The researches were carried out in the areas, in which soil transformation has be undergone and it was impacted by a long-term aridization process during the lake bottom drying up. Solonchaks crust-puffed, takyr-like soil, takyr-like soil with grey-blown desert soil, dried lakeshore soil and lacustrine soil with blown sandy cover, sand and sandy desert soil are dominated in the soil complex of the basic soil contours in south-east part of the dried lake bottom. An intensive process of deflation of light soils with the

\section{References}

Abuduwaili J, Liu D W, Wu G Y. 2010. Saline dust storms and their ecological impacts in arid regions. Journal of Arid Land, 2(2): 144-150.

Ginzbrug A I, Kostianoy A G, Sheremet N A. 2010. Satellite monitoring of the Aral Sea region. In: Kostianoy A G, Kosarev A N. The Handbook of Environmental Chemistrity. New York: Springer Science+Business Media, 147-179.

Karazhanov K D, Khaibulin A S. 2003. Soil transformation of Kazakhstan Priaralye caused by anthropogenic aridization/role of soil in landscape formation. Kazan: Fen, 137-139.

Karazhanov K D, Khaibulin A S, Alimbaev A K, et al. 2006. Annual report "To evaluate the impact of aridization on soil transformation in Kazakhstan Priaralye and to work out scientific bases on the increase of their biological productivity”. 50-53. effects of continuous dust-salt removal and dust storm formation in aeolian depressions were observed in south-east part of the Aral Sea bottom. The formation of new sandy contours with the tendency of hillock-sandy ridges formation, sandy barkhans and dunes are developed there. Thus, the transformation of soil cover in Priaralye, considering the changes in the process of anthropogenic aridization has been determined.

The study has shown that soil transformation in Priaralye proceeded under the conditions of aridization. The tendencies of negative process development (salinization and deflation) are kept and lead to further soil and eco-environment degradation in the region.

\section{Acknowledgements}

The research was supported by the Department of Ecology in Kazakh Research Institute of Soil Science and Agrochemistry named after Uspanov, Almaty, Kazakhstan.

Karazhanov R K. 2001. Anthropogenic soil transformation in the Syr-Darya River modern delta. In: Symposia Scientific Bases of Soil Fertility Reproduction, Conservation and Rational Use of Soils in Kazakhstan. Almaty: Ph.D. Thesis, 157-161.

Krivonogov S K, Kuzmin Y V, Burr G S. 2010. Environmental changes in the Aral Sea region (Central Asia): Initial results of a radiocarbon-based study. Nuclear Instruments and Methods in Physics Research Section B: Beam Interactions with Materials and Atoms, 268(7-8): 1080-1083.

Micklin P. 2010. The past, present, and future Aral Sea. Lake \& Reservoirs: Research \& Management. 15(3): 193-213.

Small E E, Giorgi F, Sloan L C, et al. 2001. The Effects of desiccation and climatic change on the hydrology of the Aral Sea. Journal of Climate, 14: 300-322. 